\title{
YEREL YÖNETIMLERDE ÇEVRE SORUNLARININ ÇEVRE HAKKI KAPSAMINDA INCELENMESI: ULUSLARARASI VE ULUSAL MEVZUAT EKSENINDE KARŞILAŞTIRMALI BİR ANALİZ
}

Yetkili Yazar | Correspondent Author: Zeynep Nur ÖZMEN

Examination of Environmental Problems in Local Governments Within the Scope of Environmental Rights: A Comparative Analysis on the Axis of International and National Legislation

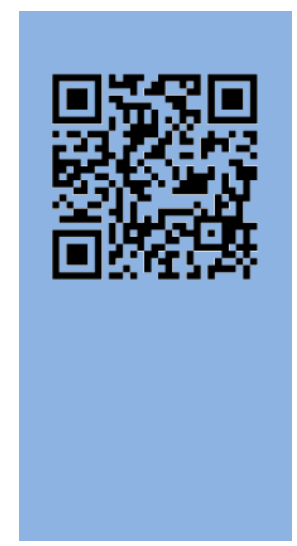

\begin{tabular}{|c|c|}
\hline & $\begin{array}{c}\text { Yazar(lar) | Author(s) } \\
\text { Mustafa KOCAOĞLU } \\
\text { Zeynep Nur ÖZMEN }\end{array}$ \\
\hline MAKALE BİLGİSİ & ÖZ \\
\hline $\begin{array}{l}\text { Anahtar Kelimeler: Yerel } \\
\text { Yönetimler, Belediye } \\
\text { Kanunu, Çevre Hakkı, Çevre } \\
\text { Sorunları }\end{array}$ & $\begin{array}{l}\text { Kentlerde yaşayan nüfusun yüksek bir hızda artış göstermesi, kentlerde } \\
\text { bir takım çevre sorunlarının artmasına neden olmuştur. Bu sorunlara } \\
\text { getirilmek istenen çözümler, konunun uluslararası düzeyde } \\
\text { tartışılmasını ve konu ile ilgili farklı kavramların ortaya çıkmasını } \\
\text { beraberinde getirmiştir. Bu kavramlar arasında “çevre hakkı" önemli yer } \\
\text { tutmaktadır. Yaşama hakkının önemli bir parçası olan çevre hakkı } \\
\text { "sağlıklı bir çevrede yaşama hakkı" şeklinde tanımlanmaktadır. } \\
\text { Çevrenin sağlıklı ve yaşanabilir kalması, bireysel bir hak ve sorumluluk } \\
\text { olduğu için çevre sorunlarının yerel düzeyde ele alındığı görülmektedir. } \\
\text { Bu anlamda çevre sorunlarının çözümü konusunda belediyeler başta } \\
\text { olmak üzere yerel yönetimlere ve yerel yönetimlerin ilgili organlarına } \\
\text { önemli görevler düşmektedir. } \\
\text { Bu çalışmada öncelikle çevre hakkı ve çevre sorunları ile ilgili kuramsal } \\
\text { ve kavramsal bir çerçeve ortaya konulmuştur. Ardından uluslararası } \\
\text { alanda çevre odaklı ilk toplantı olma özelliğine sahip olan Stockholm } \\
\text { Birleşmiş Milletler Çevre Konferansı'nın önemine değinilmiş ve yine } \\
\text { önemli belgelerden olan Yerel Gündem 21, Aarhus Sözleşmesi ve } \\
\text { Avrupa Kentsel Şartı I ve II incelenmiştir. Çalışmanın devamında çevre } \\
\text { ve çevre hakkının ulusal mevzuattaki yeri irdelenerek } 2872 \text { sayılı Çevre } \\
\text { Kanunu'ndan bahsedilmiştir. Aynı zamanda Türkiye'nin yerel } \\
\text { yönetimler alanında yeniden yapılanma çalışmalarının bir ürünü olarak } \\
\text { 5216 sayılı Büyükşehir Belediyesi Kanunu ve 5393 sayılı Belediye } \\
\text { Kanunu, konu kapsamında değerlendirilmiştir. Bu bağlamda söz konusu } \\
\text { kanunlar içerisinde belediyenin görev, yetki ve sorumluluklarından yola } \\
\text { çıarak çevresel sorunlara temas eden maddeler ele alınmıştır. Nihai } \\
\text { olarak incelenen mevzuatta çevre sorunları ve çözümleri ile alakalı } \\
\text { dağıtılan görevler ve aktörlerin önemi ve hangi sorunlara, hangi } \\
\text { maddelerle çözüm getirilmek istendiği analiz edilmiştir. }\end{array}$ \\
\hline
\end{tabular}

1 Doç. Dr., Necmettin Erbakan Üniversitesi, Uygulamalı Bilimler Fakültesi, Yönetim Bilişim Sistemleri Bölümü,_ORCID Number: https://orcid.org/0000-0002-9341-6341, e-posta: kocaoglumustafa@gmail.com

2 Y.L. Öğrn., Marmara Üniversitesi, Sosyal Bilimler Enstitüsü, Yerel Yönetimler Anabilim Dalı, ORCID Number: https://orcid.org/0000-0001-9337-480X , e-posta: ozmenzeynepnur@gmail.com 


\begin{tabular}{|c|c|}
\hline \multicolumn{2}{|c|}{$\begin{array}{l}\text { ARTICLE } \\
\text { INFORMATION }\end{array}$} \\
\hline Submission Date & $: 01 / 04 / 2021$ \\
\hline Accepted Date & $: 17 / 05 / 2021$ \\
\hline \multicolumn{2}{|c|}{$\begin{array}{l}\text { Keywords: Local } \\
\text { Governments, Municipal } \\
\text { Law, Environmental Rights, } \\
\text { Environmental Problems. }\end{array}$} \\
\hline
\end{tabular}

\begin{abstract}
An increase in the population living in cities at a high rate has led to an increase in a number of environmental problems in cities. The solutions that were intended to be brought to these problems led to the discussion of the issue at the international dimension and the emergence of different concepts related to the issue. Among these concepts, 'environmental right' is important. The right to the environment, which is an important part of the right to life, is defined as the right to live in a healthy environment.'

It is seen that environmental issues are addressed at the local level, as the environment remains healthy and livable, an individual right and responsibility. In this sense, important tasks are assigned to local governments and the relevant bodies of local governments, especially municipalities, in solving environmental problems. In this context, international texts containing the concept and subject of environmental right include issues such as ensuring urban order, reducing environmental pollution, protecting and increasing green spaces among the tasks and responsibilities that fall to local governments, which also include environmental issues

In this study, a theoretical and conceptual framework related to environmental rights and environmental problems was put forward. After that, the importance of the Stockholm United Nations Environment Conference, which is the first environmentally oriented meeting in the international arena, was mentioned and the Local Agenda 21, Aarhus Convention and European Urban Charter I and II, which are important documents, were examined. In the continuation of the study, the place of the environment and the right to the environment in national legislation was examined and the Environmental Law No. 2872 was mentioned. At the same time, the Metropolitan Municipality Law No. 5216 and the Municipal Law No. 5393 were evaluated within the scope of the subject as a product of Turkey's restructuring efforts in the field of local governments. In this context, the laws in question are based on the duties, powers and responsibilities of the municipality and the substances that come into contact with environmental problems are discussed. In the final legislation, the importance of distributed tasks and actors related to environmental problems and solutions and what problems and what substances are wanted to be solved were analyzed.
\end{abstract}

\section{Giriş}

Giresun Üniversitesi İktisadi ve İdari Bilimler Dergisi, Cilt: 7 Sayı: 2 
Kentsel nüfusun artışı dünyada yönetsel, ekonomik, toplumsal, kültürel ve çevresel koşulları değiştirmektedir. Bu değişimler mevcut sorunlara çözüm getirse de yeni sorunlara da yol açabilmektedir. Özellikle çevresel koşulların değişiminin toplum sağlı̆̆ını ve ekosistemi olumsuz yönde etkileyecek seviyede artış göstermesi, çevre sorunlarının ortaya çıkmasına neden olmuştur. (Keleş, Hamamcı, Çoban, 2015: 78). Yoğun nüfus artışı, kentleşme, sanayileşme ve doğal kaynakların kullanımının artması gibi çevre sorunlarına neden olan tüm faktörlerin daha fazla zarar vermemesi için uluslararası alanda üretilen çözümlerin içerisinde çevre hakkı kavramı önem arz etmektedir.

Çevre hakkı, "toplumların ve ekosistemdeki tüm canlıların sağlıklı ve dengeli bir çevrede yaşama yetisi" olarak tanımlanmaktadır (Bilir, Hamdemir, 2011: 145). Tanımdan da anlaşılacağı üzere çevre hakkı, insan hakları içerisinde yer alan yaşama hakkının bir uzantısıdır. Dönemsel olarak üç kuşağa ayrılan insan hakları içerisinde çevre hakkı, dayanışma hakları olarak adlandırılan üçüncü kuşak haklar içerisinde yer almaktadır. Dayanışma haklarının en önemli özelliği, talep edilen bir hak olmasının yanında bireylere sorumluluklar yüklemesidir. $\mathrm{Bu}$ sorumluluklar içerisinde çevreyi korumak ve kirletmemek, yaşam çevresini etkileyecek olan kararlarda etkin rol oynamak yer almaktadır (Bilgili, 2015: 570). Bu noktada bireylerin çevresel kararlara yön verebilmesinin yolu kent yönetiminden geçmektedir. Kısaca bireylerin, sağlıklı ve dengeli bir çevrede yaşama hakkına sahip olabilmek için öncelikle çevreye karşı sorumluluklarını yerine getirmeleri beklenmektedir.

Çevre hakkının sorumluluk yüklediği en önemli tüzel kişi ise devletlerdir. Nitekim, çevre sorunlarına yönelik olumsuzlukların 1970'lerden itibaren kritik seviyeye ulaşmasıyla birlikte, bu sorunlara çevre hakkı ekseninde çözüm üretmek amacıyla uluslararası alanda toplantılar düzenlenmiştir. Bu anlamda devletlerin ilk kez bir araya geldiği toplantı 1972'de düzenlenen Stockholm Birleşmiş Milletler Çevre Konferansı'dır. Konferans sonucunda ortaya çıkan metnin içeriğinde çevrenin korunması ve geliştirilmesi fikrinin benimsenmesi bulunmaktadır. (Keleş, Hamamcı, 1997: 18). Uluslararası alanda kent ve çevreyi bir araya getiren önemli metinlerden birisi de Avrupa Kentsel Şartı'dır. Çevre hakkı ile birlikte var olan kentli hakları, bireyin kent içerisinde çevresinin korunması ve geliştirilmesi ile ilişkilidir. Bu anlamda Şart, fiziksel çevre ve yasalarla ilgili yaptırımlar için Avrupa Konseyi’ne bir vize oluşturmak aynı zamanda Avrupa Konseyi'nin kent sorunlarına ilişkin tüm çalışma ve sonuçların bir çözümlemesini amacını taşımaktadır. 1992 yılında imzalanan Avrupa Kentsel Şartı'nın kültürlerin ve ekonomilerin değişmesiyle yenilenmesine ihtiyaç duyulduğu bilindiğinden 2008 yılında Avrupa Kentsel Şartı-II yayınlanmıştır. Ulusal alanda ise çevre sorunlarının çözümünü amaçlayan yasal düzenlemeler içerisinde merkezi yönetime sorumluluk yükleyen kanun 
2872 sayılı Çevre Kanunu'dur. Aynı zamanda T.C. 1982 Anayasası'nın 56 maddesinde, 'herkes sağllklı ve dengeli bir çevrede yaşama hakkına sahiptir' ifadesi geçmektedir. Ayrıca kentsel çevre konusunda yerel yönetimlere düşen görevler 5216 sayılı Büyükşehir Belediyesi Kanunu ve 5393 sayılı Belediye Kanunu'nda belirtilmiştir.

$\mathrm{Bu}$ çalışmada öncelikle çevre sorunları ve çevre haklarının ne olduğuna ve nasıl bir gelişim gösterdiğine dair kavramsal ve kuramsal bir çerçeve çizilmiştir. Bu çerçeve çizilirken konu ile ilgili olarak ortaya konulan uluslararası ve ulusal mevzuat ve oluşturulan politikalara da değinilmiştir. Böylece konu ile ilgili olarak uluslararası, ulusal ve özellikle yerel girişimlerin söz konusu sorun alanlarına yönelik olarak ne derecede çözüm olanakları sunduğu, karşılaştırmalı olarak değerlendirilmiştir.

\section{2. Çevre ve Çevre Sorunları}

Çevre kavramı, günlük yaşamda sıkça karşımıza çıkan kolay ve anlaşılabilir bir kavram olarak bilinse de içeriğinin araştırılması ile birlikte kavramın karmaşıklığı ortaya çıkmaktadır (Keleş, Hamamcı, Çoban, 2015: 32). Çevrenin, ilk olarak biyoloji bilimine ait bir kavram olduğu bilinmektedir. Bu anlamda kullanıldığında çevre, ekolojiye ve insanın dışında varlığını sürdüren doğal yaşama işaret etmektedir. Ancak sosyal bilimlere geçiş yapmasıyla birlikte çevre kavramına yüklenen anlamın farklılaştığ gözlemlenmektedir (Kaypak, 2017: 1038). Bu açıdan bakıldığında çevre, doğa kavramından ayrılır. Doğa, insani olayların ve yapıların dışında bir anlam içerirken çevre, somut faaliyetleri ve yön verilebilir durumları tanımlamaktadır. Bu ayrım, insanoğlunun doğaya müdahale ederek kendi çevresini oluşturması ile ortaya çıkmaktadır. Bu sebeple yapay çevre, sosyal çevre, kültürel çevre, kentsel çevre gibi insanoğlunun müdahalesi ile ortaya çıkan çevreler vardır. Bu açıdan bakıldığında çevre, doğadan daha geniş bir anlama sahiptir. Böylece çevre kavramının barındırdığı karmaşanın nedeni, insanın yaşam alanına hakim olmak istemesi olarak yorumlanmaktadır (Barry, 1999: 15).

İnsanoğlunun müdahaleleri sonucunda oluşan çevre sorunları kavramı ise gün geçtikçe insanın ve diğer canlıların yaşamını kritik seviyede etkilemektedir. İnsan faaliyetleri sonucunda ortaya çıkan çevre sorunları, sınırlı doğal kaynakların hızlı tüketimi, çeşitli nedenlerle doğal çevrenin tahribi, doğada yok olmayan maddelerin kullanımının artması gibi durumlarla birlikte ortaya çıkmaktadır. Bu faaliyetlerle birlikte insanoğlunun hem kendi türüne hem de ekolojiye zarar vermesi, dünyanın varlığını tehdit etmektedir. Böylece hayati değerlerin kirlenmesi ve tüm canlıların yaşamsal faaliyetlerinin tehlikeye girmesi çevre sorunlarıyla birlikte yaşamanın mümkün olmadığ sonucuna var1lmaktadır (Kaypak, 2017: 1039; Dunlap ve Scarce, 1991: 655). 
Çevre sorunları, insanoğlunun doğaya hakim olma isteği ve ondan yararlanma sürecinde ortaya çıkan zararlar olarak karşımıza çıkmaktadır. Bu sorunlar karşısında devletler hem ulusal hem uluslararası önlemler alarak politikalar üretmektedirler. Ancak çevre sorunlarının küresel olma özelliğinden dolayı devletler, çözüm üretirken sınırlarını kapatmak olanağına sahip değildirler. Bu sebeple her ülkenin kendi coğrafyasına özgü çevre politikası olsa bile tüm devletlerin uygulaması gereken uluslararası metinler bulunmaktadır (Batal, 2007: 18). Bu metinler içerisinde çevre sorunlarını azaltmak, önlemek ve engellemek amacıyla ortaya çıkan önemli kavramlardan birisi de 'çevre hakkı'dır.

\section{3. Çevre Hakkı}

Çevre hakkı kavramı, kişilerin bireysel olarak ya da bir araya gelerek yaşadığı çevrenin bozulmasına ya da kirlenmesine engel olabilmeleri için bir dayanak olarak ele alınmaktadır. Bilir ve Hamdemir (2011: 145) çevre hakkını 'tüm canlıların sağlıklı bir çevrede yaşama yetisi’ olarak tanımlamaktadır. Buradan yola çıkıldığında çevre hakkının merkezinde insan ve çevre kavramlarının bulunduğu bilinse de çoğu tanım insan odaklı yapılmaktadır. Kaboğlu'na (1992: 20) göre çevre hakkı, 'yaşam şartlarını olumsuz etkileyen faktörleri engellemek amacıyla her bireyin sağlıklı ve dengeli bir çevrede yaşaması için doğayı sürdürülebilir bir şekilde kullanma yükümlülüğü' anlamına gelmektedir. Tekeli (2005: 6) ise çevre hakkının bir insan hakkı olarak değerlendirilmesinden dolayı 'çevre hakkı artık yaşam hakkına göre değil, kaliteli yaşam hakkını sağlamak için yapılmalıdır' yorumunu yapmaktadır. Kısaca çevre hakkının özünü oluşturan konular, ister çevre odaklı ister insan odaklı olsun, "çevrenin korunması", "iyileştirilmesi” ve "geliştirilmesi”dir. Bu açıdan bakıldığında ekosistem içerisindeki tüm canlıların yaşama hakkı olduğu göz önünde bulundurulduğunda çevre odaklı yaklaşımın çevre etiğine uygun olması beklenmektedir (Bilgili, 2015: 568).

Sürdürülebilir, sağlıklı, ekolojik açıdan verimli, yaşanabilir gibi kavramlar ile birlikte ele alınan çevre hakkı, insan yaşamının ve sağlı̆̆ının korunması gerekliliğini vurgulamaktadır. Dolayısıyla insan haklarının önemli bir parçasını oluşturmaktadır (Rodriguez-Rivera, 2006: 83). Bu bağlamda çevre hakk1, 1979 yılında Karel Vasak birinci, ikinci ve üçüncü kuşak haklar ayrımına göre, aynı zamanda dayanışma hakkı olarak adlandırılan üçüncü kuşak haklar arasında yer almaktadır. İnsan hakları, toplumsal sınıfların sahip olduğu haklar olarak değil, tüm insanlığa ait olan ve tüm bireyler tarafından içselleştirilen haklar olarak karşımıza çıkmaktadır. Bu sebeple dayanışma hakları olarak isimlendirilen üçüncü kuşak haklar, içeriğinde evrensel konuları barındırarak tüm insanlığın dayanışma içerisinde olmasının gerekliliğini vurgulamaktadır. Böylece çoğunlukla insan odaklı ele alınan çevre hakkı, üçüncü kuşak 
haklar içerisinde yer almasından dolayı, tüm bireylerin ve toplumların bir araya gelmesini gerektirmektedir (Bilgili, 2015: 568).

İnsan hakları içerisinde yer alan çevre hakkı, yaşama hakkı ile bağdaştırıldığından diğer insan haklarının kullanılabilmesinin ilk şartıdır. Çünkü çevre hakkının insan odaklı amacı, insan yaşamının idame ettirilmesiyle birlikte sağlıklı ve dengeli çevrenin korunabilmesini sağlamaktır (Güneş, 2011: 264). Çevre hakkı, insan hakları özelinde dayanışma hakları içerisinde bulunmasından dolayı kişilere hak tanımasının yanı sıra onlara görev ve sorumluluklar da yüklemektedir. Gerçek kişilere düşen görevler arasında çevreyi korumak kirletmemek ve yaşam çevresi konusunda alınan kararlarda rol oynamak gibi yükümlülükler bulunmaktadır (Bilgili, 2015: 570; Boyle, 2006: 480). Ancak bu noktada bireylerin etkin rol oynayabilmesi için diğer aktörler ile birlikte hareket etmesi daha verimli olmaktadır. Bu bağlamda çevre konusunda görevli olan bir diğer aktör ise devlettir. Bu noktada devlet, çevreye zarar veren faaliyetlerin engellemesi, diğer tüzel kişilerin kanunlar aracılığı ile çevreye zarar vermesinin önlenmesi, çevrenin korunması ve geliştirilmesi için politika üretmesi ve uluslararası alanda çevrenin korunması için geliştirilen toplantı ve metinlere katılım sağlaması konularında sorumluluk sahibidir (Çolakoğlu, 2010: 571). Çevre hakkının bu özelliğinden dolayı hak olarak öne sürülebilmesi için öncelikle tüm kişilerin (gerçek ve tüzel) üzerine düşen vazifeleri yerine getirmesi gerekmektedir. Kısaca üçüncü kuşak insan hakları içerisinde yer alan çevre hakkı, kazandırdığı yetki ve yüklediği görevler ile bir bütün olarak karşımıza çıkmaktadır.

Çevre hakkının dayanışma hakkı olma niteliğinden kaynaklanan bir diğer özelliği ise kuşaklararası olmasıdır. Çünkü bu nitelik, çevre hakkının gelecek kuşaklarla da dayanışma içerisinde olmasını gerektirmektedir. Her yeni kuşak, 'en az kendinden önceki kuşak kadar sağlıklı ve dengeli şartlarda yaşama hakkına' sahiptir (Özdek, 2003: 109). Bu bakış açısı ile kısa vadeli kazanç sağlamak amacıyla çevresine zarar veren bugünkü kuşaklar yalnızca kendilerinin değil, çevre hakkına sahip olan gelecek kuşakların da haklarını ihlal etmektedir. Dolayısıyla bugünkü kuşağın en önemli borcu, gelecek kuşakların da faydalanabileceği sağlıklı ve dengeli bir ortam bırakmaktır (Gürseler, 2008: 202).

Çevre hakkının diğer insan hakları ile uyumsuzluğu söz konusu olduğunda bu durumun, çevre hakkı lehinde çözülmesi gerekmektedir. Örneğin çevre hakkı, mülkiyet hakkı ile çatışma halinde olmasına rağmen, birinci kuşak haklar içerisinde bulunan yaşam hakkı ile ikinci kuşak haklar içerisinde bulunan sağlık hakkı ile birbirlerini tamamlamaktadır. Bu açıdan bakıldığında çevre hakkı, yaşam hakkı ile bir bütün olduğundan vazgeçilemez bir haktır. Çünkü bu hakkın konusu doğal ve yapay olan tüm çevreyi kapsamaktadır. Amacı da ekosistemin ve insanoğlunun mevcudiyetini sürdürdükleri mekan olan çevrenin korunması, iyileştirilmesi ve geliştirilmesidir (Dadak, 
2015: 315; Anton, Shelton, 2011: 139). Bu amaç doğrultusunda çevre hakk1 ile diğer hakların çatışma halinde olması durumunda, çevre hakkının lehine olan kararlar tercih edilmektedir.

\section{Yerel Yönetimlerin Çevre Hakkı Kapsamındaki Görevlerinin Uluslararası Mevzuattaki Yeri}

Çevre hakkı, ilk olarak 1972 yılında Türkiye'nin aralarında bulunduğu 113 ülkenin Stockholm'de düzenlenen Birleşmiş Milletler İnsan Çevresi Konferansı'nda ortaya çıkan metinde yer almıştır (Turpancı, 2018: 7). Ancak 1992 yılında gerçekleştirilen Rio Konferans1, sonucunda ortaya çıkan metinler sayesinde yerel yönetimlerin çevreyi korunması ve iyileştirilmesi konusunda daha etkin olmuştur. Bu noktada göze çarpan en önemli belge 'Gündem 21' eylem planıdır. Bu planın ortaya koyduğu sorunların ve önerilen çözümlerin genellikle yerel çalışmalara dayalı olması sebebiyle 'Yerel Gündem 21 'e dönüşmesi kent yönetimine çeşitli görevler yüklemiştir. Ayrıca bu tarihsel sürecin devamında (30 Ekim 2001) yerel kurumlara ve bireylere önemli haklar tanıyan ve görevler yükleyen Aarhus Sözleşmesi de çevre hakkına önemli katkılar sağlamıştır. Son olarak birincisi 1992 yılında, ikincisi ise 2008 yılında kabul edilen Avrupa Kentsel Şartı, kent yönetimine ve kenttaşlara, kentsel çevrelerine olan sorumluluklarını ve çevre haklarının mevcudiyetini bildiren bir belge olarak karşımıza çıkmaktadır.

\subsection{Birleşmiş Milletler İnsan Çevresi Konferansı (Stockholm Bildirgesi)}

İsveç'in Stockholm kentinde 5 - 16 Haziran 1972 tarihinde gerçekleşen Birleşmiş Milletler İnsan Çevresi Konferansı, çevre hakkının gelişimini ve hukuki düzleme taşınmasını sağlayan ilk ve en önemli gelişme olarak kabul edilmektedir. Bunun nedeni çevre sorunlarının ilk kez uluslararası alanda dile getirildiği bir ortam oluşturmasıdır. Böylece uluslararası çevre hukukunun meydana gelmesi çevre sorunları ile mücadelede başlangıç noktası olarak kabul edilmektedir (Özdek, 1993: 73).

BM İnsan Çevresi Konferansı'nda gelişmiş olan ülkeler sanayileşmenin getirdiği kirlilikler, çevre sorunları ve çözümü için atılabilecek adımlar gibi konulara yönelirken; gelişmemiş veya gelişmekte olan ülkeler ise ekonomik kaygılarını dile getirmişlerdir. Sanayileşme ve ekonomik kalkınma amacının sebep olduğu çevre sorunlarının çözümü için ortaya çıkan yükümlülüklerin eşit paylaşılmamasının gerekliliği belirtilmiştir. Özetle bu konferansta tüm katılımcı ülkeler, çevre sorunlarına çözüm aramak ile gelişmemiş ve gelişmekte olan ülkelerin ekonomik kalkınma isteği arasında köprü kurmak için çalışmışlardır (Çiftçioğlu, 2019: 120). 
Konferans sonrasında ortaya konulan bildirgede insanın çevreye verdiği zararları, bu zararların küresel nitelikte olması ve ülkelerin gelişmişlik düzeylerine göre çevre sorunlarının çözümüne yaklaşımı ele alınmaktadır. Ülkelerin gelişmişlik düzeyine göre çevrenin korunması için yapılması gerekenlerin listelendiği bu metnin birinci ilkesinde çevre hakk1, 'kaliteli bir çevrede onurlu ve yeterli yaşam şartları sağlanmış olarak yaşamak insanın en temel hakkıdır. Insan aynı zamanda bugünün ve gelecek kuşakları için çevreyi koruma ve iyileştirmenin sorumluluğunu taşır.' şeklinde değinilmiştir (UN, 1972: 4-5).

\subsection{Birleşmiş Milletler Çevre ve Kalkınma Konferansı (Rio Konferansı) - Yerel Gündem 21}

3-14 Haziran 1992 tarihinde Birleşmiş Milletler Çevre ve Kalkınma Konferansı, Brezilya'nın Rio de Janeiro kentinde düzenlenmiştir. Stockholm Konferansı'ndan 20 yı1 sonra bir araya gelen ülkeler, bu süre zarfinda uygulanan çevre politikalarını değerlendirmişlerdir (Keleş ve Ertan 2002: 212). 179 ülkenin katılım gösterdiği BM Çevre ve Kalkınma Konferansı, pek çok yönü ile 20. yüzyılın en önemli konferansı olarak literatürde yerini almıştır. Bunun nedeni, katılım oranının yüksek olması, içeriğinin rehber oluşturacak niteliğe sahip olması ve ülkelerin ekonomik kalkınma politikaları ile ilişkili olmasından kaynaklanmaktadır. Bu özellikleri nedeniyle BM Çevre ve Kalkınma Konferansı, çevre odaklı düzenlenen diğer faaliyetlerden ayrılmaktadır (Güneş, 2012: 87).

BM Çevre ve Kalkınma Konferansı sonucunda beş temel uluslararası belgeden biri olan Gündem 21 Eylem Planı'nın yerel yönetimlere ve kenttaşlara sorumluluklar yüklemesi ile 'Yerel Gündem 21' ortaya çıkmaktadır. $\mathrm{Bu}$ eylem planı, dünya kentlerindeki yerel yönetimler ile sivil toplumun bir araya gelerek kent gündemini oluşturmak amacı etrafında birleşmesiyle hem katılımcı demokrasinin hem de kentsel yaşam çevresinin kalitesinin geliştirilmesi hedeflenmektedir (mfa.gov.tr). Bu anlamda Yerel Gündem 21, ilk olarak yerel sürdürülebilirliği sağlamak için uzun vadeli bir strateji planının hazırlanması ve uygulanması amacıyla yerel boyutta Gündem 21'in hedeflerine ulaşabilmek için bir yöntem olarak karşımıza çıkmaktadır (Emrealp, 2005: 27).

BM Çevre ve Kalkınma Konferansı'nın ilkelerini hayata geçirmek amacıyla Yerel Gündem 21, "çevrenin ve ekonominin etkilendiği alanlarda; yerel yönetimlerin, devletlerin, kalkınma örgütlerinin ve uluslararası kuruluşların yapmaları gereken faaliyetlerin yer aldığı bir eylem planı”dır (Keleş ve Ertan, 2002: 217). Bu amaçla Yerel Gündem 21 eylem planı, 'Sosyal ve Ekonomik Boyutlar', 'Kalkınma İçin Kaynakların Korunması ve Yönetimi', 'Etkin Grupların Rollerinin Güçlendirilmesi’ ve ‘Uygulama 
Yöntemleri’ olarak adlandırılan dört temel başlıktan oluşmaktadır. Bu başlıklardan da anlaşılacağı üzere plan, yerel bölgelerde etkin çevre yönetiminin orada yaşayan bireylerin etkin katılımı ile gerçekleşeceğinin altını çizmektedir (Zeytin, Kırlığlu, 2014: 244).

\subsection{Aarhus Sözleşmesi}

25 Haziran 1998 tarihinde imzaya açılan ve 30 Ekim 2001 tarihinde 26 devlet tarafından kabul edilerek yürürlüğe giren asıl ismi ile 'Bilgiye Erişim, Karar Verme Sürecine Halkın Katılımı ve Yargıya Başvuru Sözleşmesi', çevre hukukunun önemli belgelerinden biridir. Literatüre katkısı sebebiyle sözleşme, insan hakları ile çevrenin korunması arasındaki bağlantıyı sağlayan ve devletlerin vatandaşlarına karşı sorumluluklarının olduğunu belirten ilk uluslararası belge niteliğindir. Çevre hukuku alanında diğer çevre odaklı metinlerden farklı bir yere sahip olan Aarhus Sözleşmesi, bugünkü ve gelecek kuşakların kendi çevrelerini koruması ile ilgili hususlarda haklarının korunmasını sağlamak amacıyla 'çevre hakkının unsurları' olarak adlandırılan çevresel bilgiye erişim, katılım ve yargıya başvuru hakkını garanti altına alan bir sözleşmedir (Akbaba, 2016: 143).

Sözleşme, çevre sorunlarının çözümünde etkili olabilmek için farklı bakış açılarının geliştirilmesi ve tüm çevre odaklı aktörlerin çözüme katkı sağlaması gerektiğini vurgulamaktadır (Ceyhan, 2019: 53). Bunu uygulayabilmek için çevre hakkının varlığını somutlaştıran ve çevre hukukuna önemli katkılar sağlayan uluslararası bir belge olarak karşımıza çıkmaktadır. İçeriği ve katkıları bakımından küresel niteliğe sahip olan sözleşme, Türkiye tarafından çeşitli çekinceler sunularak imzalanmamıştır. Ancak ulusal mevzuat incelendiğinde bilgiye erişim, katılım ve yargıya başvuru konusunda pek çok düzenlemenin olduğu göz çarpmaktadır. Bu anlamda sözleşmede yer alan ilkelerle büyük oranda benzeşen hukuki düzenlemelerin geliştirilmesi ve çevresel demokrasi anlayışının benimsenmesi için sözleşmeye taraf olmanın olumlu sonuçlar doğuracağ1 yorumu yapılmaktadır (Güneş, 2010: 329).

\subsection{Avrupa Kentsel Şartı I - II}

18 Mart 1991 tarihli ve Avrupa Konseyine bağlı olarak gerçekleştirilen Avrupa Yerel ve Bölgesel Yönetimler Konferansı'nda kabul edilen Avrupa Kentsel Şartı, ortak bir kent politikası oluşturmayı amaçlayan bir belgedir. Yerel yönetimler ve kentsel konuları içeren şart, bir rehber niteliğinde karşımıza çıkmaktadır (Akhan, 2019: 5). Bu amaçla yerel hizmetlerdeki verimliliğin artmasında, toplumsal ve kültürel faaliyetler için imkanların oluşturulmasında ve yerel dayanışma duygusunun geliştirilmesinde önemli bir 
yere sahiptir (Mutlu, Yücel Batmaz, 2013: 180). Yerel bazda etkin ve verimli bir yönetim yönteminin belirtildiği şartın temel felsefesi, yerel yönetimlerin kentin yaşam kalitesini arttırmasını sağlayan görevlerini tanımlamak, kentsel gelişimin niteliklerini ortaya koyarak küresel ilkeler oluşturmak, kentli hakları ve dolayısıyla çevre haklarını vurgulayarak nitelikli bir kent çevresi oluşturmayı sağlamak olarak belirtilmektedir (Akkoyunlu Ertan, 1997: 42).

Şart, kentlerde çevre ve doğa ilkesi ile yerel yönetimlerin tıpkı diğer kurumlar gibi doğal kaynakları akılcı bir şekilde kullanması ve israftan kaçınması gerektiğini belirtmektedir. Aynı zamanda çevre kirliliğinin önlenmesi amacıyla yerel yönetimlerin politika geliştirmesini ve çevrenin korunması konusunda halkın bilinç kazanması için faaliyetler yürütülmesi gerektiğini vurgulamaktadır. Kenttaşların sağlıklı bir çevrede yaşaması için geliştirilen ilkelerin ortak amacı, kentsel yapıların hem mimari açıdan hem de kentin tarihi dokusunu kaybetmemesi açısından korunmasını sağlamaktır. Böylece kenti, kendine has özelliklerini kaybetmeden geliştirmek ve yenilemek mümkün hale gelmektedir (Mutlu, Yücel Batmaz, 2013: 181-183). Çevre hakkını içeren ilkeleri ile Şart, taraf olan kentleri daha yaşanılabilir hale getirmek ve temel insan haklarından olan kaliteli yaşam hakkını gerçekleştirmek amaçlanmaktadır.

Avrupa Kentsel Şartı ile atılan bu yerel adım, dünyanın yaşadığı değişim ve gelişim ile birlikte bir güncellemeye ihtiyaç duymuştur. Geçen on beş yıllık süre zarfında küresel anlamda kent ve kentli ihtiyaçlarının yeninden tanımlanması gerektiği konusu ele alınmıştır. Bu nedenle 27-29 Mayıs 2008 tarihinde Avrupa Konseyi tarafından düzenlenen Avrupa Yerel ve Bölgesel Yönetimler Konferansı sonucunda 'Avrupa Kentsel Şartı-II: Yeni Bir Kentlilik İçin Manifesto’ ismiyle kabul edilmiştir. Böylece bu manifesto, yenilenen ihtiyaçları karşılamak ve sorunlara çözüm bulmak amacıyla ortaya çıkmıştır (Akhan, 2019: 16).

Avrupa Kentsel Şartı-II, yeni bir kent ve kentlilik anlayışı ile yola çıkarak önerilerin bulunduğu başlıklardan oluşmaktadır. Çevre hakkı kavramını içeren. 'Sürdürülebilir Kentler ve Kasabalar' başlığı, mevcut küresel çevre sorunlarının engellenmesi konusunda yerel yönetimleri sürdürülebilirlik konusunda teşvik etmektedir. Kentlerin daha sürdürülebilir türden bir gelişim sağlaması adına kentsel ekolojinin geliştirilmesi amaçlanmaktadır (European Urban Charter - II: Manifesto For a New Urbanity, 2008: 5 - 14).

\section{Yerel Yönetimlerin Çevre Hakkı Kapsamındaki Görevlerinin Ulusal Mevzuattaki Yeri}


$\mathrm{Bu}$ başlık altında çevre hakkının yer aldığı ulusal mevzuat olarak 2872 sayılı Çevre Kanunu, 5393 sayılı Belediye Kanunu ve 5216 sayılı Büyükşehir Belediyesi Kanunu incelenmektedir. Bu doğrultuda çevre hakkının uygulanabilmesi adına halkın katılım sağlayabileceği en yakın kuruluş olan yerel yönetimlerin görevlerine değinilmektedir. 2872 sayılı Çevre Kanunu maddelerinde bulunan çevrenin korunması ve iyileştirilmesi konularında çoğunlukla yerel yönetimlerin görevlendirildiği görülmektedir. 5393 ve 5216 sayılı kanunlarda ise kent yönetiminin görevleri arasında çevrenin sağlıklı koşullara sahip olması önemli bir yere sahiptir.

\subsection{Sayılı Çevre Kanunu}

Gerçekleştirilen uluslararası konferanslar ve ortaya çıkarılan belgeler neticesinde Türkiye, 9 Ağustos 1983 tarihinde 2872 sayılı Çevre Kanunu'nu yayımlayarak çevrenin korunması konusunda önemli bir adım atmıştır. Amacı, bütün canlıların ortak alanı olan çevrenin sürdürülebilirliğini arttırmak ve sürdürülebilir kalkınma hedefleri etrafında korunmasını sağlamak olarak belirlenmiştir (Çevre Kanunu, 1983: 1). Böylece önemli yaşam alanları olarak gelişen kentlerin sürdürülebilirlik kavramı ile birlikte inşa edilmesi ve geliştirilmesi ön koşul olarak sunulmaktadır.

Çevre Kanunu ile çevrenin korunması, iyileştirilmesi ve kirliliğin önlenmesi konusunda sunulan ilkeler içerisinde yerel yönetimlere görevler yüklemektedir. Bu durum çevre yönetiminin tanımı içerisinde bulunan '...doğal ve yapay çevresel ögelerin sürdürülebilir kullanımını ve gelişmesini sağlamak amacıyla yerel, bölgesel, ulusal ve küresel düzeyde belirlenen politikaların uygulanması' ifadesinden anlaş1lmaktadır.

Çevre hakkının koruyucu-geliştirici ilkelerinden olan katılım hakkı Kanun'un 3/e maddesinde 'çevre politikalarının oluşmasında katılım hakkı esastır. Bakanlık ve yerel yönetimler çevre hakkının kullanılabileceği her türlü alanı vatandaşlara ve topluluklara sunmakla yükümlüdür.' şekilde ifade edilmektedir. (Çevre Kanunu, 1983: 3). Bu anlamda kanun, herhangi bir bölgede ortaya çıkan bir çevre sorununu önlemek veya gidermek amacıyla bireysel ve toplumsal olarak müdahale edilebileceğinin ruhsatını vermektedir. Böylece hem vatandaşa en yakın hizmet veren hem de katılım sağlanabilen kurumlar arasında en ulaşılabilir konumda olan yerel yönetim birimleri öne çıkmaktadır.

Çevre Kanunu, ulusal anlamda çevrenin korunması amacıyla karşımıza çıkan en önemli mevzuat olarak bilinmektedir. Bu nedenle ekolojiyi olumsuz anlamda etkileme ihtimali olan her faaliyet göz önüne alınarak hazırlanan kanun, çeşitli idari yaptırımları ve para cezalarını da içermektedir. 


\subsection{Sayılı Büyükşehir Belediye Kanunu ve 5393 sayılı Belediye Kanunu}

Yerel yönetimlerin küresel boyutta değer kazanması ile birlikte Türkiye'de belediyecilik anlayışına yönelik radikal reformların gerekliliğinin ön plana çıktığı gözlemlenmektedir. Ancak bu gerekliliğin reformun içeriği ve yapısı konusundaki soru işaretleri nedeniyle, bir takım fikir ayrılıklarına neden olduğu bilinmektedir. Bu durumun giderilmesi için atılan adımlar arasında sivil toplum kuruluşlarının ve akademik çevrenin görüşlerinin alınması, küresel siyaset ve idari gelişmelerin göz önüne alınarak reformların kalıcı ve kapsayıcı olması yer almaktadır. Böylece merkezi yönetimin, görev ve sorumluluklarını vatandaşa daha yakın bir konumda bulunan yerel yönetimlerle paylaşarak kamu hizmetlerini daha verimli bir hale getirmek için önemli bir adım attığı belirtilmektedir. (Bulgan, 2008: 122). Bu adımların kanıtı olarak 10 Temmuz 2004 tarihinde 5216 sayılı Büyükşehir Belediyesi Kanunu ve 3 Temmuz 2005 tarihinde 5393 sayılı Belediye Kanunu karşımıza çıkmaktadır.

Ulusal ölçekte bakıldığında çeşitli değişikliklere uğrayarak bugün geçerli olan 5216 sayılı Büyükşehir Belediyesi Kanunu, büyük alan yönetimine ilişkin kamusal hizmet yönetiminin oluşturulması faaliyetleri içerisindeki önemli düzenlemelerden bir tanesidir (Soydal, 2012: 92). Bu doğrultuda kanun, büyükşehir belediyesi yönetiminin hukuki konumunu düzenlemeyi, hizmetleri planlı, programlı, etkin, verimli ve uyum içerisinde yürütülmesini sağlamayı amaçlamaktadır. Çevre hakkı kapsamında 7/i maddesinde belirtilen 'sürdürülebilir kalkınma ilkesini bağlı olarak çevrenin, tarım alanlarının ve su havzalarının korunmasını sağlamak, ăgaçlandırma yapmak, halk să̆lı̆̆ına ve çevreye olumsuz etkisi olan iş yerlerini kentin belirli alanlarına toplamak, inşaat ve benzer faaliyetler sonucunda ortaya çıkan atıkların depolama alanların belirlemek ve bu malzemelerden dolayı çevre kirliliğine meydan vermeyecek önlemleri almak, katı atı yönetim planını yapmak' görevlerini yerine getirmekle yükümlüdür (5216 sayılı Büyükşehir Belediyesi Kanunu, 2004: 1-3). Böylece bu kanun büyükşehir belediyelerine, kent ve kenttaş sağlığını riske atma ihtimali olan her faaliyeti önleme veya durdurma yetkisi tanımakta ve çevre hakkının sağlanabilmesi için bir takım sorumluluklar sunmaktadir.

5393 sayılı Belediye Kanunu'nda ise belediyenin kuruluşunu, organlarını, yönetimini, görev, yetki ve sorumluluklarını düzenlemek amaçlanmaktadır. Kanunun devamında kent çevre planlaması ve yönetimi ile ilgili ilkeler 'Belediyenin Görev ve Sorumlulukları' başlığg altında yer alan 14. maddesinin (a) ve (o) bendinde şu şekilde yer almaktadır: 'a) Imar, su ve kanalizasyon, ulaşım gibi kentsel alt yapı, çevre ce çevre să̆lı̆̆l, temizlik ve katı atık, ăgaçlandırma, park ve yeşil alan hizmetlerini yapar veya 
yaptırır. o) Halk să̆lı̆̆ına zararlı ve çevreye olumsuz etkisi olan iş yerlerini kentin belirli yerlerine toplamak, çeşitli inşaat malzemeleri atıkları nedeniyle oluşabilecek çevre kirliliklerinin önüne geçmekle görevlidir' (5393 sayılı Belediye Kanunu, 2005: 6-8).

5216 sayılı Büyükşehir Belediye Kanunu ile karşılaştırıldığında daha genel bir niteliği sahip olan 5393 sayılı Belediye Kanunu'nda, büyükşehir belediyeleri ile ilgili konularda 5216 sayılı kanunda belirtilmeyen bir durum ortaya çıktı̆̆ında 5393 sayılı kanun hükümlerinin geçerli olacağ 1 belirtilmektedir (Eken, 2009: 192). Ancak çevre ve çevre hakkı söz konusu olduğunda kanunlar tarafindan yapılan görevlendirmelerin her koşulda belirtildiği gözlemlenmektedir. Böylece teoride kentlerin sağlıklı ve kaliteli yaşam alanları olarak değerlendirilmesi mümkündür.

\section{Sonuç}

18. yüzyılın ikinci yarısından itibaren ortaya çıkan sanayileşme ve sanayileşmenin çok yönlü etkileri ile birlikte çevre sorunlarının artışı hız kazanmıştır. Bu durum her geçen gün, insanlığın 'doğaya hakim olma' düşüncesi ile pekişmiştir. 20. yüzyıla gelindiğinde ise nüfus ile birlikte kentleşmenin de artması, çevre sorunlarını kritik seviyeye yükseltmiştir. Son tahlilde küresel boyutta yankı uyandıran çevre kirlilikleri için önlem alınması gerektiği gündeme gelmiştir ve 1970’li yılların başında yılında gerçekleşen Birleşmiş Milletler İnsan Çevresi (Stockholm) Konferansı ile başlayan toplantılarda, uluslararası düzeyde ilk kez, çevre sorunlarının konuşulmasına ve çözüm üretilmesine yönelik çeşitli çalışmalar gündeme gelmeye başlamıştır.

Çevre hakkı, çevre sorunlarına bir çözüm olabileceği düşüncesiyle ortaya atılan bir kavramdır. Bunun nasıl işleyeceği konusu ise her vatandaşın çevrenin korunması, dolayısıyla kendi yaşamını sağlıklı bir şekilde devam ettirebilmesi olarak açıklanmaktadır. Çevre hakkına sahip olan herkesin aynı zamanda çevreye karşı sorumlu olması, kavramın farklı yönlerinden biri olarak ele alınmaktadır. Dolayısıyla ulusal ve uluslararası mevzuatta bu iki yönü ile karşımıza çıkmaktadır. İlk kez 1972 yılında BM İnsan Çevresi Konferansı sonucunda ortaya çıkan metinlerde karşımıza çıkan çevre hakkının, daha sonra pek çok ülkede gündeme gelerek ilgili mevzuatta yer aldığı göze çarpmaktadır.

Türkiye'de ise çevre hakkı, ulusal ve yerel mevzuatta yerini alarak hem bir hak hem de bir sorumluluk olarak karşımıza çıkmaktadır. Bu iki yönü ile çevre hakkının, 2872 sayılı Çevre Kanunu, 5393 sayılı Belediye Kanunu ve 5216 sayılı Büyükşehir Belediyesi Kanunu'nda yer aldığı görülmektedir. Bu kanunların içeriğinde çevre sorunlarına çözüm niteliğinde ele alınan çevre hakkı, ilk olarak kurumların bir görevi olarak karşımıza çıkmaktadır. Özellikle Çevre ve Şehircilik Bakanlığı bu konuda öne çıkan en önemli kurumdur. Bu durum, 5393 ve 5216 sayılı yerel yönetimlere ilişkin kanunlarda 2018 
yılında yapılan değişiklikle doğal ve yapay çevrenin korunması ile ilgili görevlerin İçişleri Bakanlığı yerine Çevre ve Şehircilik Bakanlığg'na bağlanması ile açıklanmaktadır. Geçerli kanunlar çerçevesinde geliştirilen politikalar (idari cezalar, kurumların görevleri, vergiler, vb.) çevrenin korunması için önemli adımlardan bir tanesidir. Ancak bu tek başına yeterli değildir. Üretilen politikaların etkin ve verimli bir şekilde uygulanabilmesi için belirlenen aktörler de konunun önemli bir unsurudur. $\mathrm{Bu}$ kapsamda çevre hakkına sahip kurumlardan biri olan yerel yönetimler, hem çevrenin korunmasında hem de çevre hakkının sağlanabilmesinde rol oynamaktadır. Dolayısıyla çevrenin korunması ve iyileştirilmesini konu alan ulusal mevzuat hükümleri, çoğunlukla kentlerde olmak üzere, insan çevresinde meydana gelebilecek çoğu çevresel olumsuzluğu öngörmektedir.

Çevre hakkı konusunda uluslararası ve ulusal mevzuat karşılaştırıldığında çoğunlukla birbirleriyle uyumlu olduğu görülmektedir. Bu anlamda küresel bir konu olan çevre sorunları için geliştirilen çözümlerin öncelikle uluslararası alanda tartışılarak ortaya çıkması ve devamında çevre sorunlarının muhatabı olan ülkelerin teşvik edilmesi doğal bir süreçtir. Böylece çevrenin korunması ve iyileştirilmesi amacıyla üretilen ulusal ve uluslararası tüm politikaların çevre hakkını içermesi, gerekli bir durum haline gelmiştir. Bunun en temel sebebi, çevre hakkına sahip olan tüm kişilerin aynı zamanda çevrenin korunmasından sorumlu olması ve yaşam kalitesini etkileyecek olmasıdır.

\section{Kaynakça}

Akbaba, A. (2016), İnsan Hakları Hukukunda Üçüncü Kuşak Haklar. İstanbul: Legal Yayıncılık.

Akhan, A, E. (2019), Avrupa Kentsel Şartı Bağlamında Bisiklet Paylaşım Sistemlerinin İncelenmesi: Çanakkale Örneği. Basılmamış Yüksek Lisans Tezi.

Anton, D.K., Shelton, D.L. (2011), Environmental Protection and Human Rights. USA: Cambridge University Press

Akkoyunlu Ertan, K. (1997), 'Kentli Hakları', Amme Iddaresi Dergisi. 30, 32 - 48.

Barry, J. (1999), Environmental Sociology: Controversy and Continuity. New York: Routledge.

Batal, S. (2007), Yerel Yönetimler Açısından Türkiye ve Avrupa Birliği Çevre Politikalarının Mukayeseli Değerlendirilmesi. Basılmamış Yüksek Lisans Tezi.

Belediye Kanunu (2005). Resmi Gazete (Sayı: 5393). https://www.mevzuat.gov.tr/MevzuatMetin/1.5.5393.pdf Erişim Tarihi: 27.01.2021 
Bilgili, M.Y. (2015), ‘Anayasal Bir Hak olarak Çevre Hakkı', Çankırı Karatekin Üniversitesi Sosyal Bilimler Enstitüsü Dergisi, 2 (6), 563 - 584.

Bilir, F., ve Hamdemir, B. (2011), 'Çevre Hakkı ve Uygulaması', International Conference on Evrasion Economies, 2, 143 - 149.

Boyle, A. (2006), 'Human Rights or Environmental Rights? A Reassessment', Fordham Environmental Law Review. 18, 471 - 511).

Bulgan, E. (2008), Avrupa Yerel Yönetimler Özerklik Şartı ve 5393 Sayılı Belediye Kanunu. (Basılmamış Doktora Tezi).

Büyükşehir Belediye Kanunu. (2004, 3 7). Resmi Gazete (Sayı: 5216). https://www.mevzuat.gov.tr/MevzuatMetin/1.5.5216.pdf Erişim Tarihi: 27.02.2021

Ceyhan, H. (2019), Çevre Hakkı Çerçevesinde Iran'ın Urmiye Gölü'ndeki Uygulamaları. Basılmamış Yüksek Lisans Tezi.

Coenen, F. (2009), Public Participation and Better Environmental Decisions. United States: Springer Netherlands.

Çevre Kanunu. (1983, 9 8). Resmi Gazete (Sayı: 2872). https://www.mevzuat.gov.tr/MevzuatMetin/1.5.2872.pdf Erişim Tarihi: 27.02.2021

Çiftçioğlu, H., Aydın, A.H. (2019), 'Türkiye'de Yerel Yönetimler ve Çevre Sorunlarının Çözümündeki Sorumlulukları, Rolleri ve Önemi', Al-Farabi International Journal on Social Sciences, 3, 117 - 128.

Çolakoğlu, E. (2010), ‘Haklar Söyleminde Çevre Eğitiminin Yeri ve Türkiye'de Çevre Eğitiminin Anayasal Dayanakları', TBB Dergisi. 88, 151 - 171.

Dadak, K. (2015), 'Yeni Kuşak Hak Olarak Çevre Hakkı', Uyuşmazlık Mahkemesi Dergisi, 5, 309 - 326.

Dunlap, R., Scarce, R. (1991), 'Poll Trends: Environmental Problems and Protection', The Public Opinion Quarterly, 55, 651 - 672.

Eken, İ. (2009), Avrupa Yerel Yönetimler Özerklik Şartı Hükümleri Çerçevesinde 5393 Sayılı Belediye Yasası ve 5216 Sayılı Büyükşehir Belediyesi Yasası. Basılmamış Yüksek Lisans Tezi.

Emrealp, S. (2005), Yerel Gündem 21 Uygulamalarına Yönelik Kolaylaştırıcı Bilgiler Elkitabl, İstanbul: Birmat Matbaası

Güneş, A. (2010), ‘Aarhus Sözleşmesi Üzerine Bir İnceleme’, Gazi Üniversitesi Hukuk Fakültesi Dergisi.14, 299 - 333. 
Güneş, A. (2011), 'Yeni Anayasa Tartışmaları Bağlamında Çevre', Gazi Üniversitesi Hukuk Fakültesi Dergisi. 15, 259 - 283.

Güneş, A. (2012), 'Uluslararası Çevre Hukuku Üzerine Bir İnceleme' İstanbul Üniversitesi Hukuk Fakültesi Mecmuası. 70, 83 - 114.

Gürseler, İ. (2008), 'İnsan Hakları, Çevre, Anayasa', TBB Dergisi. 75, 199 - 208.

https://5cidade.files.wordpress.com/2008/11/the-european-urban-charter.pdf The European Urban Charter, Erişim tarihi: 24.02.2021.

Kaypak, Ş. (2017), Çevre Hakkı ve Kentsel Alanlarda Uygulanması Zhakipbek Altaev, Zharkynbike Suleımenova, Ömer Okan Fettahlığlu (Ed). Al Farabi 1. Uluslararası Sosyal Bilimler Kongre Kitabı. Gaziantep: İKSAD Yayınevi, 1037 - 1059.

Kaboğlu, İ. (1992), Çevre Hakkı. İstanbul: İletişim Yayınları.

Keleş, R., Ertan, B. (2002), Çevre Hukukuna Giriş. Ankara: İmge Kitabevi.

Keleş, R., Hamamc1, C. (1997), Çevrebilim. Ankara: İmge Kitabevi.

Keleş, R., Hamamcı, C., Çoban, A. (2015), Çevre Politikası. Ankara: İmge Kitabevi.

Mutlu, A., Yücel Batmaz, N. (2013), Türkiye'de Kent Hakkl. Ankara: Orion Kitabevi.

Özdek, Y. (1993), Çevre Hakkl. Ankara: TODAİE.

Özdek, Y. (2003), Insan Hakkı Olarak Çevre Hakkı. Ankara: Türkiye ve Ortadoğu Amme İdaresi Enstitüsü Yayınları.

Rodriguez-Rivera, Luis E. (2006), 'The Human Right to Environment and the Peaceful Use of Nuclear Energy', Denver Journal of International Law \& Policy, 35, 173-192.

Soydal, Ö, M. (2012). 5216 Sayılı Büyükşsehir Belediye Yasası Kapsamında Metropoliten Alanlarda Sınır Tespitinin Değerlendirilmesi. Basılmamış Yüksek Lisans Tezi.

Tekeli, İ. (2005), 'Çevre Hakkına Yerelden Yaklaşmak, Sivil Toplum Geliştirme Merkezi', Ankara, http://panel.stgm.org.tr/vera/app/var/files/c/e/cevre-hakkinayerelden-yaklasmak-ilhan-tekeli.pdf (Erişim:15.09.2020).

Turpanc1, A. (2018), Çevre Hukukunun Gelişiminde Uluslararası Örgütlerin Rolü. Basılmamış Yüksek Lisans Tezi. 
UN, (1972). Report Of The United Nations Conference On The Human Environment, Stockholm, Sweden, 5-16 Haziran.

Zeytin, M., Kırlıoğlu, H. (2014), 'Çevre Yönetim Sistemi ve Yerel Yönetimler', Akademik Sosyal Araştırmalar Dergisi. 5, 238 - 254. 